\title{
Bio-Control of Alternaria alternata during Banana Storage by Purified AFP Using Isoelectric Focusing Technique
}

\author{
Hassan Barakat \\ Department of Food Science, Faculty of Agriculture, Benha University, 13736 Moshtohor, Kaliuobia, Egypt \\ Email: hassan.barakat@fagr.bu.edu.eg
}

Received 31 May 2014; revised 2 July 2014; accepted 15 July 2014

Copyright (C) 2014 by author and Scientific Research Publishing Inc. This work is licensed under the Creative Commons Attribution International License (CC BY). http://creativecommons.org/licenses/by/4.0/ c) (i) Open Access

\section{Abstract}

Interestingly, antifungal protein AFP was purified from Aspergillus giganteus supernatants with modified isoelectric focusing procedure after adaptation of the secretion conditions. Subsequently, the antifungal activity as well as the mode of action against Alternaria alternata was tested in vitro. Moreover, different concentrations of AFP were applied to banana fruits for 15 days at $20^{\circ} \mathrm{C}$ in vivo.

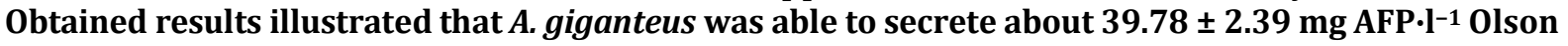
medium. The employed ammonium sulfate (AS $75 \%$ ) precipitation procedure followed by dialysis steps yielded about 16 - $22 \mathrm{mg}$ AFP.l $\mathrm{I}^{-1}$ culture supernatant with general mean of $18.67 \pm 1.98 \mathrm{mg} \cdot \mathrm{l}^{-1}$. The lost amount of AFP during purification using AS and $3 \mathrm{KDa}$ cut-off dialysis membrane is about $50 \%$ thus, purification procedure must be further improved. Indeed, concluded results from MIC and hyphal extension inhibition test noticed that AFP was efficiently affected by either growth or hyphae form of $A$. alternata in vitro. The MIC of AFP against A. alternata was $2 \mu \mathrm{g} \cdot \mathrm{ml}^{-1}$. However, short, thick and highly septated hyphae with damaged constricted apical regions extruding from condensed mycelium aggregates in treated hyphae compared to the untreated culture was remarkably shown. The mode of action of in vitro experiment manifested that AFP was effective to act the fungal cell and permeabilize the cell membrane of $A$. alternata. Furthermore, the in vivo experiment showed that AFP could reduce post-harvest decay on banana caused by A. alternata. AFP at concentration of 15 and $25 \mu \mathrm{g} \cdot \mathrm{ml}^{-1}$ exhibit Alternaria decayed reduction by $45.45 \%$ and $\mathbf{7 7 . 2 7 \%}$, respectively. While no Alternaria decayed area was observed when $50 \mu \mathrm{\mu g} \cdot \mathrm{ml}^{-1}$ was applied during the storage time. Quantification of DNA by species-specific PCR could exude a positive correlation between the DNA amount and decayed area. In conclusion, AFP can be efficiently used as a bio-preservative agent during storage and handling of banana fruits, and considered as an excellent biological alternative to combat secondary growth of filamentous fungi.

\section{Keywords}

Antifungal Protein (AFP), Alternaria alternata, Isoelectric Focusing, Antifungal Activity, 


\section{Introduction}

Antimicrobial proteins and peptides have been isolated from a wide range of plant and micro-organisms species. More recently it has become increasingly clear that these types of antimicrobial peptides play an important role in food bio-preservatives. In this approach, many antimicrobial and antifungal peptides were isolated and successfully used to prevent some foods from the microbial and fungal deteriorations [1]. Among the antifungal proteins produced by filamentous fungi, the imperfect Ascomycetes A. giganteus is characterized by its ability to secret some antifungal peptides. A small-sized antifungal peptide with destructive effects on fungal growth has been observed [2]. The antifungal protein AFP secreted by A. giganteus is one prominent peptide bearing great potential for future antifungal strategies. A. giganteus secretes two basic proteins in cultivation media containing high amounts of peptides. The first one is: $\alpha$-Sarcin, the protein with an anticancer activity, has been a ribosome-inactivation protein (RIP) recorded by [3], whereas the second peptide has been shown to specifically inhibit the growth of filamentous fungi and was therefore named antifungal protein (AFP). The AFP consists of 51 amino acids, resulting in a molecular weight of $5.81 \mathrm{kDa}$. AFP is a small and basic peptide that exerts extremely potent antifungal activity against human- and plant-pathogenic fungi without affecting the viability of bacteria, yeast, plant and mammalian cells [4]. The isoelectric point was estimated to be 8.8; thus, the protein is positively charged under physiological conditions. Lacadena et al. [5], who used an extra chromatography Sephadex G-25 column, reported that an overall yield of $5-10 \mathrm{mg} \cdot \mathrm{AFP} \cdot \mathrm{l}^{-1}$, whereas [6] were able to purify $3.4 \mathrm{mg}$ homogenous AFP $\cdot l^{-1}$ by Carboxymethyelcellulose (CMC-52) as cation exchange chromatography with blue Sepharose (CL-6B) affinity chromatography. Recently, Liu et al. [2] purified $\alpha$-Sarcin and AFP by chitin affinity column chromatography and gel filtration, and obtained $3.45 \mathrm{mg} \cdot \mathrm{AFP} \cdot \mathrm{l}^{-1}$. No last AFP producers used heat shock at the end of cultivation process. Theis [7] found that $17 \mathrm{mg}$ purified AFP. $\mathrm{l}^{-1}$ were obtained with CMC-52 and Sephadex G-50 column. Most recently $16.22 \mathrm{mg} \cdot \mathrm{AFP} \cdot \mathrm{l}^{-1}$ were purified using Cellulose phosphate (Cph) as cation exchange chromatography and Sephadex G-50 with incubation the culture at $28^{\circ} \mathrm{C}$ for about $100 \mathrm{hrs}$ followed by an additional incubation period for $17-20 \mathrm{hrs}$ at $37^{\circ} \mathrm{C}$ [8]. A few studies were established for purification different antifungal peptides applying the isoelectric focusing procedure [9]-[11], where no one used this technique for purification of AFP from A. gigenteus so far.

AFP affects the membrane alterations exclusively in AFP-sensitive fungi. It is predominantly localises on outer layer and accumulates within defined areas as AFP receptors of the cell wall. It could also be demonstrated that AFP readily permeabilizes the membrane of AFP-sensitive strains [12]-[15]. Alternatively, AFP has been observed that interacts with unknown membrane components and might be responsible of disruption of chitin synthases within the plasma membrane which mainly dependent on the sterole and sphingolipid profile of plasma membrane [16] [17]. Most recently, it was shown that AFP inhibits in vivo the activity of chitin synthases in AFP sensitive fungi thereby inhibit the hyphal elongation [18] [19].

A. alternata was reported as human and plant pathogen which caused leaf and fruits brown spots in many fruits and vegetable [20] [21]. Many species of the genus Alternaria commonly cause spoilage of various food crops in the field or post-harvest decay. Due to their growth even at low temperatures, they are also responsible for spoilage of these commodities during refrigerated transport and storage. Several Alternaria species are known producers of toxic secondary metabolites-Alternaria mycotoxins such as alternariol, alternariol monomethyl ether, altenuene, altertoxins I, II, III, tenuazonic acid and other less toxic metabolites. There are several reports on the mutagenicity and genotoxicity of alternariol, and alternariol monomethyl ether. A large number of Alternaria metabolites have been reported to occur naturally in food commodities e.g. fruits, vegetables, cereals and oil plants [22]. The recent reports concluded that A. alternata caused Alternaria leaf spots of banana and dominated in banana friuts [20]. In recent study the A. Alternate shown to be very sensitive to AFP and had been inhibited on tomato and mango during storage [23].

As AFP is consider as an attractive alternative for food preservation and suggest several technological uses such as food bio-preservatives and development of antifungal agents [23] [24]. The present investigation was carried out to purify AFP from A. giganteus applying modified isoelectric focusing procedure. Carry out the quantitative analysis of AFP purification procedure as well as characterize the AFP antifungal activities and its 
mode of action on some pathogenic fungi. One potential application using banana as fruit module and A. alternata as pathogen had been investigated.

\section{Material and Methods}

\subsection{Strains}

A. giganteus IfGB0902V and A. Alternata IfGB0203 were obtained from Institut für Gärungsgewerbe, Berlin, Germany.

\subsection{Banana Fruits}

Fresh banana (Musa acuminata L.) was obtained from the local vegetable supermarket at Berlin, Germany in fresh commercial level of maturity after the artificial ripping was achieved to about $90 \%$.

\subsection{Fungal Strains Propagation}

A. alternata IfGB0203 was cultivated on PDA [25]. After 7 - 10 days the spores suspensions were obtained by washing the media surface with $0.05 \%$ Triton- $\mathrm{x}-100$ solution by sterilize cotton buds. The spore suspensions were filtrated with sterilized Nylon films to remove the mycelium derivates and the spores count was calculated by Thomas cell. While for DNA isolation and prepare pure DNA for the PCR assay, A. alternata was propagated using $\mathrm{PDB}$ at $28^{\circ} \mathrm{C}$ for 2 days.

\subsection{AFP Production, Precipitation and Dialysis}

A. giganteus was cultivated on Olson medium as mentioned previously by [8] and the supernatant was obtained by filtration, centrifuged to get clear supernatant. The ammonium sulfate was added to the supernatant gradually to reach $75 \%$ of saturation at $4{ }^{\circ} \mathrm{C}$ for protein precipitation with constant stirring overnight. The precipitated protein was collected by centrifugation at 10,621 $\mathrm{xg}$ for $15 \mathrm{~min}$. The protein pellet was dissolved in minimum volume of PBS buffer $\mathrm{pH} 7.0$ then the protein solution was extensively dialyzed through (3 kDa cut-off) membrane against water overnight with cyclic system. The dialysed protein matrix was freeze dried then mixed with ampholyte (Bio-Rad) with $\mathrm{pH}$ range 3 - 10. On the other hand, aliquot of cultural supernatant was also freeze dried and applied to AFP separation.

\subsection{Isoelectric Focusing Separation of AFP}

The mixed dialysed protein with ampholytes was subjected to an isoelectric focusing electrophoresis (IEF, BioRad, Figure 1) in a vertical apparatus and focused at $400 \mathrm{~V}$ for a period of $4-5 \mathrm{~h}$. Approximately $20 \mathrm{ml}$ of prepared protein was applied to get about 20 fractions in $\mathrm{pH}$ range $3-10$ according to the used ampholytes. The $\mathrm{pH}$ of collected fraction was measured and SDS-PAGE (Bio-Rad) using $20 \mu \mathrm{l}$ from each fraction was performed

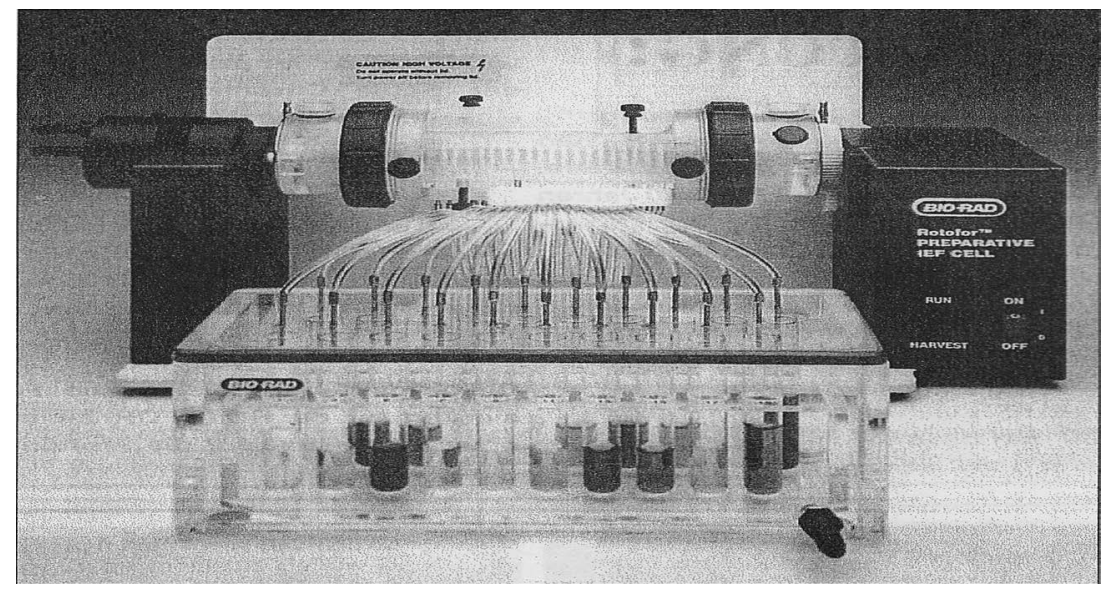

Figure 1. Vertical isoelectric focusing electrophoresis apparatus (Bio-Rad). 
in presence of a standard protein marker (Bio-Rad, 6.9 - $203 \mathrm{kDa}$ ). Protein band was visualized by staining with silver stain [26]. The AFP bands were observed at the respected molecular weight according the protein marker. The AFP fractions at $\mathrm{pH}$ range of (8.6 - 9.8) were pooled and the purity was examined using size exclusion chromatography column packed with Sephadex G-50. The protein concentration was determined spectrophotometrically according to [27] using the "Micro-Protein Assay" kit from Bio-Rad (München). The calibration standard curve was performed with different concentrations of either $\gamma$-globulin or bovine serum albumen (BSA).

\subsection{AFP Antifungal Activity in Vitro}

\subsubsection{Hyphal Extension Inhibition Assay}

Antifungal activity was assayed using a hyphal extension-inhibition method as described by [28]. Tested strains were cultivated in the centre of Petri dish containing PDA. After incubating at $28^{\circ} \mathrm{C}$ for $48 \mathrm{~h}$, sterile filter paper disks were placed on the agar surface in front of the advancing fungal mycelium. Then $20 \mu \mathrm{l}$ of protein preparations containing AFP with different concentrations as $50,100,250,500 \mu \mathrm{g} \cdot \mathrm{ml}^{-1}$ were applied to each disk as well as buffer without AFP as a control was used. The plates were incubated at $28^{\circ} \mathrm{C}$ for an additional $48-72 \mathrm{~h}$ and the inhibition effect was observed.

\subsubsection{Determination of the Morphological Changes}

A. alternata was cultivated in PDB medium. One thousand spore or conidia were added to $200 \mu \mathrm{l}$ of culture medium containing AFP at different concentrations ranged from $0-50 \mu \mathrm{g} \cdot \mathrm{ml}^{-1}$ in microtiter plate (Greiner, Frickenhausen). After $72 \mathrm{~h}$ of incubation with continuous agitation at $120 \mathrm{rpm}$, the mycelium from each concentration was washed with phosphate buffer (pH, 7.0) then fixed with Poly-L-Lysine (PLL) on glass slid and covered with slid cover [29]. The morphological attributes were microscopically diagnosed.

\subsubsection{Determination of the Minimal Inhibitory Concentration (MIC)}

The in vitro activity of AFP was determined, $10^{3}$ spores of A. alternata were added to $200 \mu$ lof culture medium containing AFP at different concentrations ranged from $0-50 \mu \mathrm{g} \cdot \mathrm{ml}^{-1}$. After $72 \mathrm{~h}$ of incubation with continuous agitation, the minimal AFP concentration that prevented growth of a given test organisms was determined and declared as the minimal inhibitory concentration (MIC). MIC was defined as the lowest AFP concentration which resulted in complete inhibition of growth. Percentage of growth inhibition was calculated according to [30].

\subsubsection{Determination of AFP Mode of Action}

The SYTOX-Green uptake assay was performed according to the method described by [13] [31]. One thousand spores of the fungal test strain were cultivated in 96-well microtiter plate containing $200 \mu \mathrm{l}$ PDB medium. After $42 \mathrm{~h}$ of incubation at $28^{\circ} \mathrm{C}$, AFP and SYTOX-Green were added to final concentration of $50 \mu \mathrm{g} \cdot \mathrm{ml}^{-1}$ and $0.2 \mu \mathrm{M}$, respectively. After addition incubation period for $1 \mathrm{~h}$, the mycelium were washed with Tris buffer $(\mathrm{pH}, 6.0)$ and fixed with Poly-L-Lysine (PLL) on glass slid then covered with slid cover. Fluorescence color images were captured using Argus X1 software under fluorescence light in absence and presence of AFP.

\subsection{AFP Antifungal Activity in Vivo}

\subsubsection{Effect of AFP at Different Concentrations on Control of A. alternata in Vivo}

Fresh banana fruits were washed with tap water, then surfaced-disinfected with $2 \%$ sodium hypochlorite for 2 min, cleaned with sterilized water and air dried prior to wounding. Spore suspensions of A. alternata were obtained by flooding 7 - 10 day-old PDA culture of pathogen with sterile distilled water containing $0.05 \%(\mathrm{w} / \mathrm{v})$ Triton-x-100. Spore concentration of the pathogen was determined by Thomas cell and adjusted with sterile distilled water to $10^{6}$ spore $\cdot \mathrm{ml}^{-1}$. Fruits were wounded with a sterile cylinder puncher to make one uniform 2-mm deep by 2-mm wide wound on their peel (5 wounds/fruit) then inoculated using prepared spore suspension of $A$. alternata by inject $5 \mu \mathrm{l}$ into each wound. After $0.5 \mathrm{~h}$ under clean pinch, the wounded fruits were divided in 6 groups, each group contain 10 fruits. For AFP treatments, aliquots of $0,5,15,25$ and $50 \mu \mathrm{g} \cdot \mathrm{AFP} \cdot \mathrm{ml}^{-1}$ were sprayed on the infected wounds using small atomizer set (about $2 \mathrm{ml}$ for each 2 fruits), where 2 wounded fruits were treated with one individual AFP concentration. Fruits were packed separately in carton packages and cov- 
ered with polyethylene sheets then kept at $20^{\circ} \mathrm{C}$ with approximately $94 \% \mathrm{RH}$. The diameters of the infected area were measured subsequently after $4,7,10,12,14$ and 15 days.

\subsubsection{Quantification of A, alternata Growth on Banana Fruits by PCR}

The infected area of each fruit was collected; DNA was isolated and purified according to [32]. The DNA concentration was measured after mixing with TE buffer $\mathrm{pH} 7.5$ and measured at $260 \mathrm{~nm}$ and $280 \mathrm{~nm}$ according to [33]. All DNA isolates were subjected to the specific PCR using $1 \mu \mathrm{l}$ with the standard PCR reaction. A standard curve applying different concentrations of pure A. alternata DNA in range from 0.5 to 100 ng was performed between the DNA concentrations and their relative fungal DNA amounts and the calculating equation was obtained using the exponential regression module (Microsoft Excel, 2010). The relatively DNA amounts were calculated using the obtained equation after measuring the PCR-Fragments intensity by Kodak program. Both PCR test for pure A. alternata DNA and A. alternata isolated DNA from banana were carried out under the same conditions.

\subsubsection{Species-Specific PCR}

PCR for the isolated DNA was used to amplify the DNA using AAF2/AAR3 primer

(TGCAATCAGCGTCAGTAACAAAT)/(ATGGATGCTAGACCTTTGCTGAT) in the standard reaction solution. DNA amplification was performed in the thermal cycler machine using PCR set program. The programs were carried out an initial 3.0 min denaturation at $95^{\circ} \mathrm{C}$; then 35 cycles of $30 \mathrm{~s}$ at $95^{\circ} \mathrm{C}, 30 \mathrm{~s}$ at $64^{\circ} \mathrm{C}$ annealing temperature and $60 \mathrm{~s}$ at $72^{\circ} \mathrm{C}$, followed by a final extension of $5 \mathrm{~min}$ at $72^{\circ} \mathrm{C}$ and cooled down to $4{ }^{\circ} \mathrm{C}$. In order to identify the strains according to DNA size, horizontal electrophoresis gel was performed. DNA amplified products were mixed with stopping buffer and run through $1.5 \%$ agarose gel in the presence of $0.5 \times$ TAE buffer at $120 \mathrm{~V}$ for 35 to $45 \mathrm{~min}$. After 20 min staining in Ethidium bromide solution, the bands became visible under UV light. Identification of A. alternate was carried out by comparing the individually DNA fragment to the DNA marker GeneRuler ${ }^{\mathrm{TM}}$ DNA Ladder Mix 100 - 10,000 bp [25]. The relative fungal DNA amounts were calculated by measuring the PCR-Fragment intensity for all PCR bands using Kodak ID program v., 3.6 and mean of triplicate \pm SE was calculated and performed by Excel program [8].

\section{Results}

\subsection{Optimization of AFP Purification from A. giganteus by Isoelectric Focusing Technique}

The isoelectric focusing (IEF) is a widely used procedure in protein purification. It is based on the principle that the protein placed in a $\mathrm{pH}$ gradient within an electric field will migrate toward either the cathode or anode until it reaches a $\mathrm{pH}$ at which there is no net charge on the protein molecule [9]-[11].

In order to analyse the antifungal activity of the AFP produced by A. giganteus against A. alternata as plant pathogenic fungi and also to utilize the AFP in a selected food stuff. A liquid isoelectric focusing using BioRad's Rotofor cell (Figure 1), which separate the sample into 20 fractions was used. To establish this protocol, the AS was applied at wide range of concentration (25\% - 90\%) to detect the best concentration for precipitate of high AFP yield, Figure 2. The obtained result illustrated a positive relationship between isolated protein yield

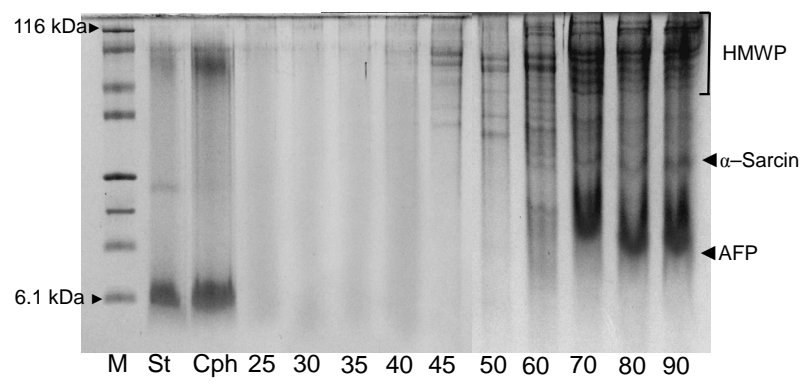

Figure 2. SDS-PAGE of different precipitated protein form the cultural supernatants by different ammonium sulfate concentrations compared to isolated AFP by cellulose phosphate (Cph). M: protein marker (6.1 - $116 \mathrm{kDa})$, St: APF standard and 25 - 90: ammonium sulfate; HMWP: high molecular weight protein. The most isolated proteins are $\alpha$-sarcin and AFP. 
and AS concentration. The best concentrations which were able to precipitate high amount of AFP are from $60 \%$ to $90 \%$. While no precipitated AFP had been observed applying $25 \%$ to $50 \%$ AS concentration. Therefore, the suggested concentration for precipitate the AFP would be $75 \%$ to realise the purification protocol.

This system could be able to purify AFP in either precipitated protein pellet or lyophilised medium with/or without dialysis, Figure 3. However, performing of dialysis process could be better for improving the procedure adequacy by removing the AS residues. Otherwise, the AFP was able to be isolated even from the lyophilized supernatant as can be shown in Figure 3. The comparing yield data indicated that using the AS precipitation followed by dialysis step could be much easier and beneficial for AFP production on large scale.

Interestingly, the whole AFP purification procedure has been established and drowns down (Figure 4). Applying the AS with obtained supernatant at $75 \%$ overnight at $4{ }^{\circ} \mathrm{C}$, separation the protein pellet followed by dialysis overnight then IEF had been achieved. Hence, the isoelectric point of AFP is 8.8 [5], fractions between 8.6 to 9.8 demonstrated the pure AFP. According to SDS-PAGE in Figure 4, the AFP separation yield was in-

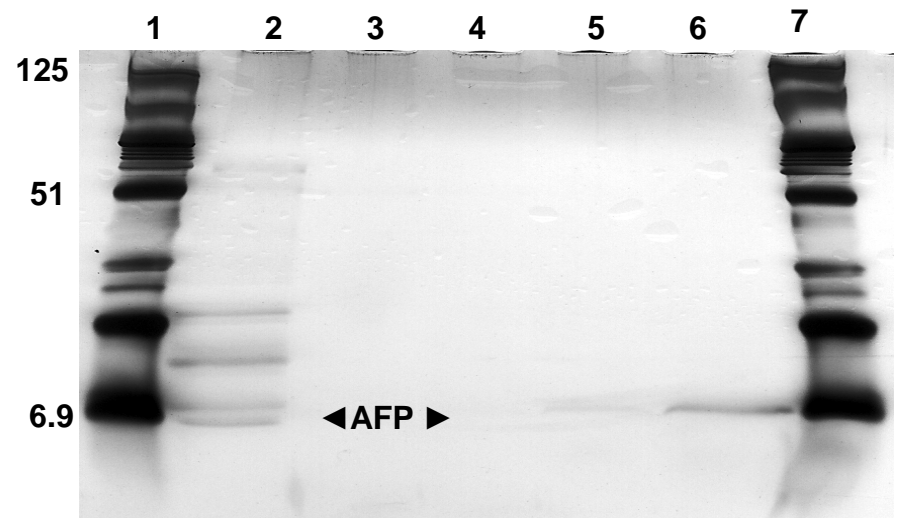

Figure 3. SDS-PAGE of isoelectric focusing separated fractions from the lyophilized cultural supernatant. Lanes (1 and 7): Protein marker (6.9 - $125 \mathrm{kDa}$ ), Lanes (2): lyophilized supernatant mixed with ampholyt pH 3 - 10 run without any additional treatments and Lanes (3 - 6): different protein fractions $7.68,8.2,8.80$ and 9.48 belong to 3, 4, 5 and 6 from freeze-dried cultural supernatant, respectively.

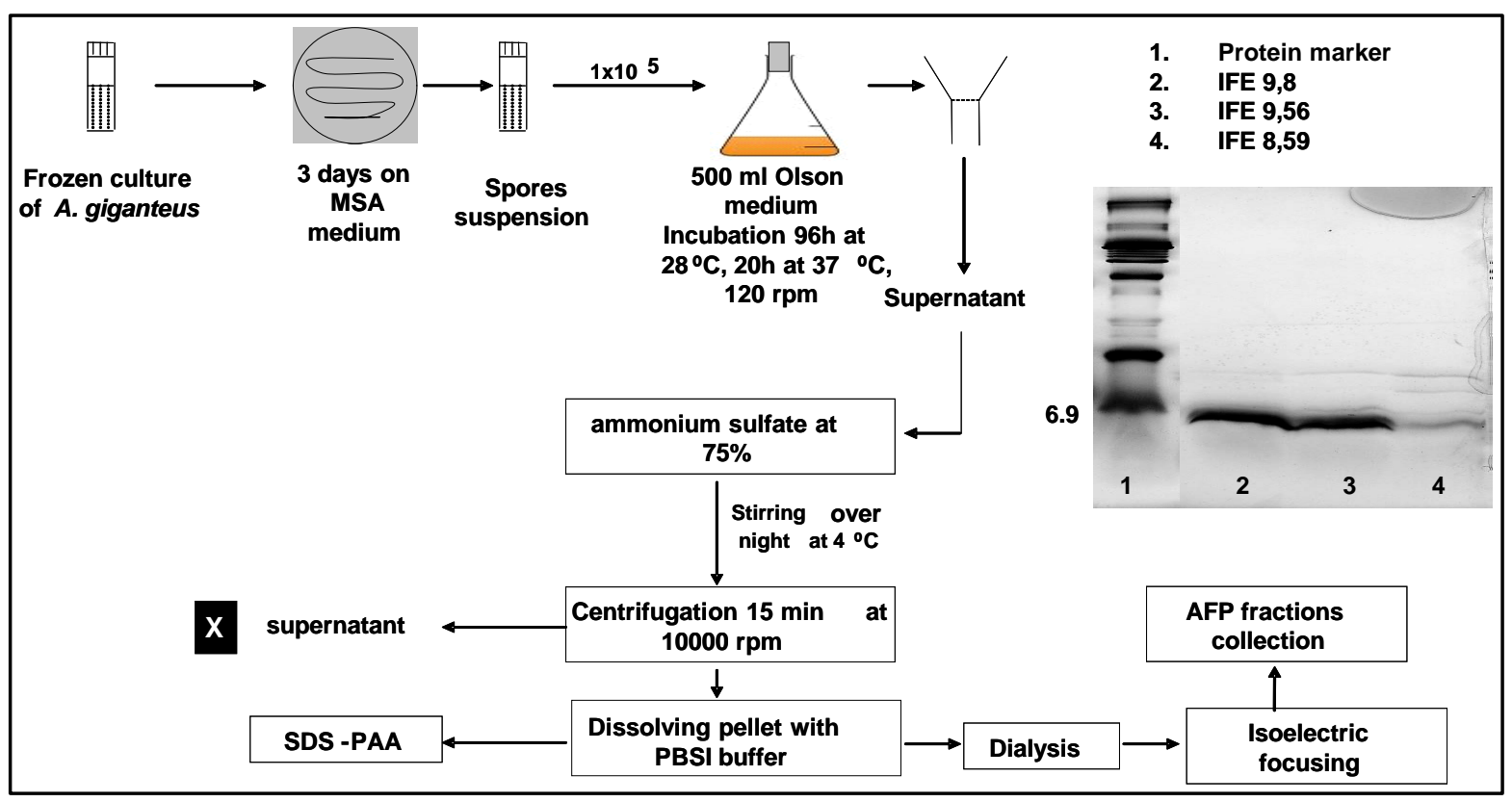

Figure 4. Flow chart of the adapted AFP production and purification procedure. 
creased at $\mathrm{pH} 8.59$ - 9.8. However, the isolated protein at fraction 9.56 and 9.8 yielded AFP amount higher than AFP amount at 8.59 fraction. Furthermore, the AFP fractions are able to be lyophilized and still in active form.

The quantification analysis of established protocol of AFP purification was illustrated. However, obtained results illustrated that $A$. giganteus is able to secrete about $39.78 \pm 2.39 \mathrm{mg} \cdot \mathrm{AFP} \cdot \mathrm{l}^{-1}$ Olson medium. The employed ammonium sulphate (AS 75\%) precipitation procedure followed by dialysis steps yielded about $16-22 \mathrm{mg} \cdot \mathrm{AFP} \cdot \mathrm{l}^{-1}$ culture supernatant with general mean of $18.67 \pm 1.98 \mathrm{mg} \cdot \mathrm{l}^{-1}$. The lost amount of AFP during purification using AS and 3KDa cut-off dialysis membrane is about $50 \%$ thus, purification procedure should be further improved.

\subsection{Characterization of AFP Antifungal Activity}

It is known from previous studies that AFP inhibits the growth of filamentous fungi but has no effect on the growth of bacteria, yeast and mammalian cells [13] [24]. In addition, the qaulitative and quantitative antifungal activity as well as effect on morphological shape and mode of action were investigated. The antifungal activity of isolated AFP by the cation exchanger chromatography against A. alternata has been recently investigated [23]. Hyphal extension inhibition of $A$. alternata using different AFP concentrations was determined and the result was shown in (Figure 5). AFP at concentration ranged from $50-500 \mu \mathrm{g} \cdot \mathrm{ml}^{-1}$ exhibit strongly antifungal activity by inhibition the hyphae elongation. The inhibition zone was relatively correlated with increasing the concentration.

Studying the effect of AFP on morphological shape demonstrated that around $1 \mu \mathrm{g} \cdot \mathrm{AFP} \cdot \mathrm{ml}^{-1}$ could affect the fungal hyphae shape (Figure 6). Incubation of fungal strain with AFP exudes short, thick and highly septated

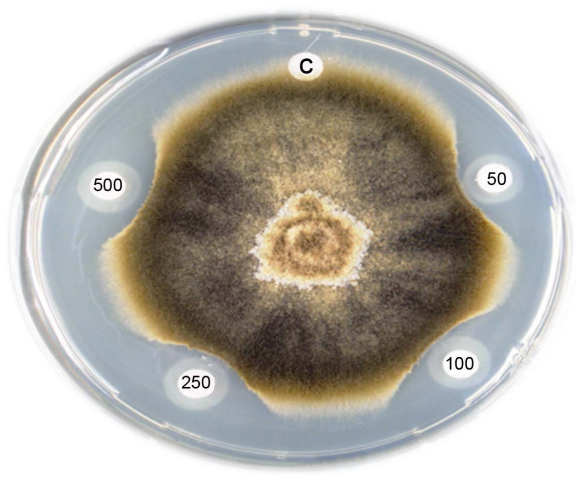

Figure 5. Direct inhibition of fungal growth by AFP, A. alternate was cultured on potato dextrose agar (PDA). Crescents surrounding disks indicate the inhibition of hyphae extension. Disks contained 50,100, 250 and $500 \mu \mathrm{g} \cdot \mathrm{ml}^{-1}$ of AFP and sterilize buffer used as a control (C).

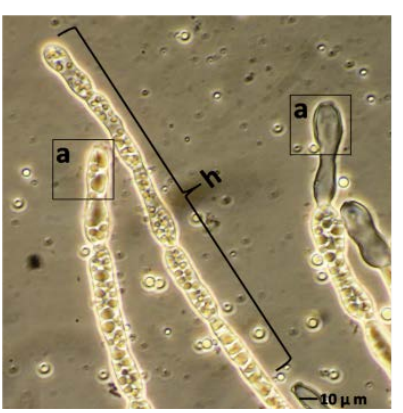

(a)

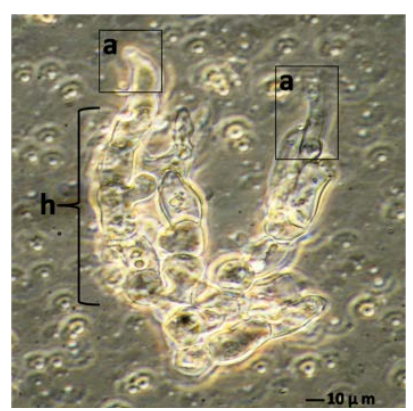

(b)

Figure 6. Morphological changes induced in A. alternata mediated by AFP at concentration of $1 \mu \mathrm{g} \cdot \mathrm{ml}^{-1}$ which was cultivated in PDB for 3 days. (A) Normal apical (a) and hyphae (h); (b) Damaged apical (a), abnormal hyphae (h) and hyphae not grow more means no new hyphae branches. 
hyphae with damaged constricted apical regions extruding from condensed mycelium aggregates in treated hyphen compared to the untreated culture was remarkably shown (Figure 6(b)). Interestingly, the microscopic diagnostic shows high cell released components in the medium of treated strain with AFP as a result of cell damaging or disruption Figure 6(b). The most dramatically effect of AFP on growth of sensitive strain was inhibiting the new hyphae formation as well as affects the grown mycelium therapy reducing the fungal biomass. Moreover, the MIC of AFP against A. alternata was $2 \mu \mathrm{g} \cdot \mathrm{AFP} \cdot \mathrm{ml}^{-1}$ by liquid medium test using $10^{3}$ spore $\mathrm{ml}^{-1}$.

\subsection{Determination of Membrane Permeabilization}

The AFP mode of action related to membrane permeabilization by the SYTOX-Green uptake to check the activity of AFP on A. alternata was investigated. In a qualitative approach, an assay was based on the uptake of the fluorogenic SYTOX-Green dye to check the binding of AFP to the cell wall and plasma membranes of sensitive fungi which was followed by permeabilization of the membrane. A. alternata was tested for AFP-induce membrane permeabilization. Therein results of this investigation are shown in Figure 7. Strong SYTOX-Green fluorescent related to uptake of the SYTOX-Green fluorogenic dye and staining of the nucleic acid was observed when the strain was incubated with SYTOX-Green and $25 \mu \mathrm{g} \cdot \mathrm{AFP} \cdot \mathrm{ml}^{-1}$ (Figure 7(b)). In contrast, it has no effect from SYTOX Green dye on fungal growth which only displays a very faint fluorescence when not bound to DNA. No DNA-SYTOX-Green fluorescence was detected when A. alternata was incubated with SYTOXGreen in the absence of AFP (Figure 7(d)). This observation confirmed that AFP cause intercellular uptake of the dye under these conditions.

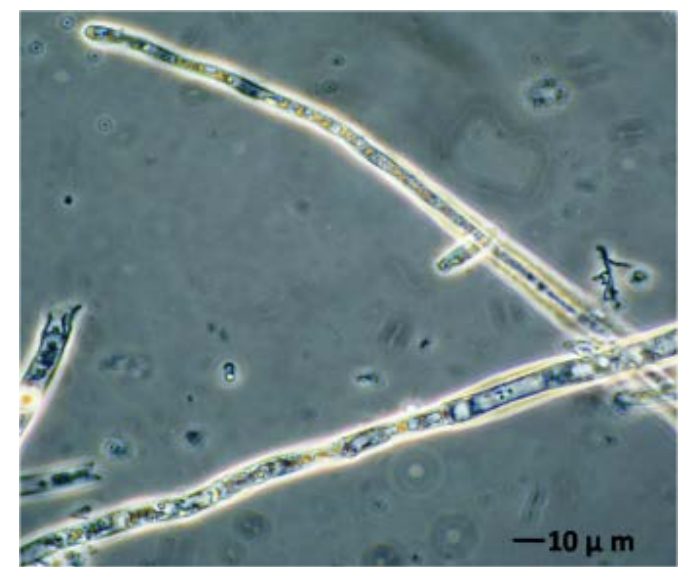

(a)

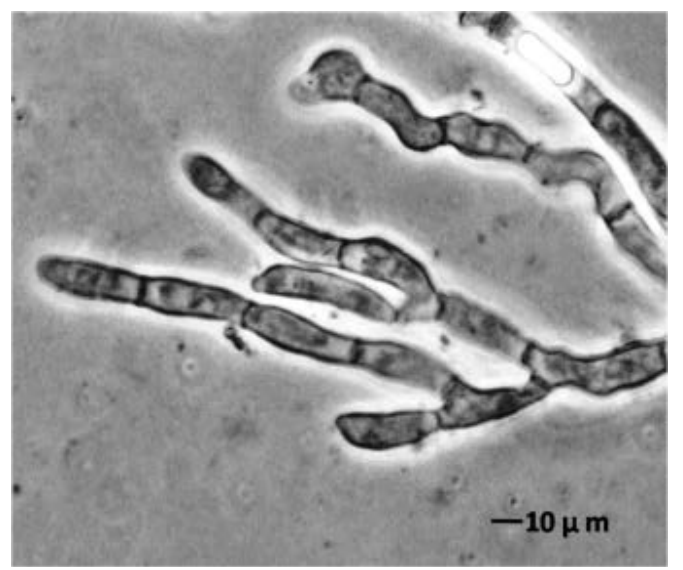

(c)

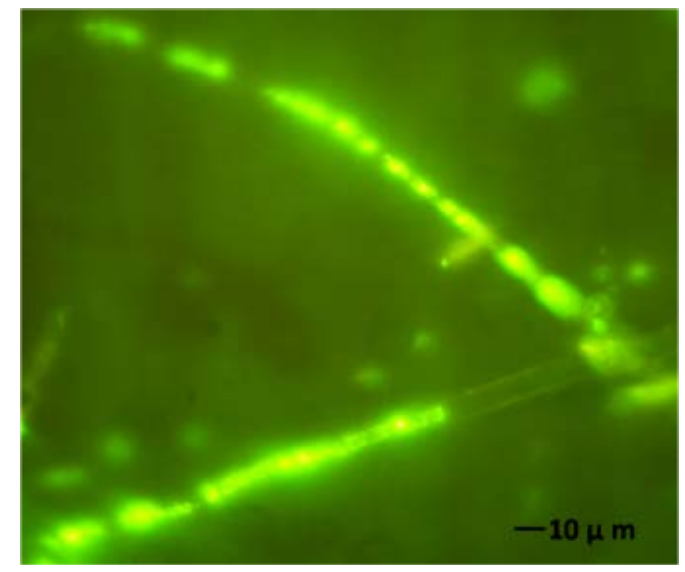

(b)

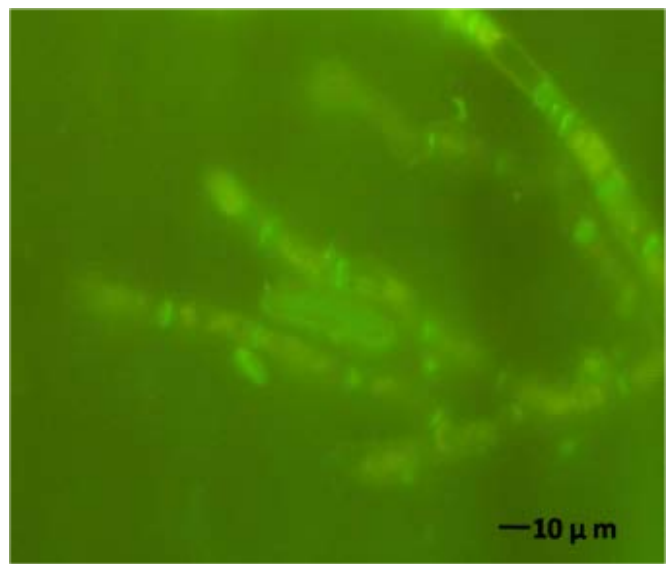

(d)

Figure 7. A. alternata SYTOX-Green uptake in absences or presence of AFP. (a) Light photo; and (b) Florescence photo for treated strain with $25 \mu \mathrm{g} \cdot \mathrm{ml}^{-1}$ AFP; (c) Light photo and (d) Florescence photo without AFP. The strain was grown in PDB media for 42 hrs before examination. 


\subsection{Effect of AFP at Different Concentrations on Control of A. alternata in Vivo}

The decayed area of artificially infected-wounded banana fruits by A. alternata spores was illustrated in Figure 8. The results indicated that when artificially infected-wounded bananas were sprayed with different AFP concentrations, the growth of A. alternata was partly or totally inhibited depends on the applied concentration, Figure 8 and Figure 9 . However, applying AFP at $15 \mu \mathrm{g} \cdot \mathrm{ml}^{-1}$ demonstrated about $45 \%$ growth reduction in banana fruits after 15 days.

While, the reduction percentage of decayed banana skin area treated by $25 \mu \mathrm{g} \cdot \mathrm{ml}^{-1}$ was 77.27 after $15^{\circ} \mathrm{C}$ days at $20^{\circ} \mathrm{C}$. However, spraying of the wounded banana fruits by $50 \mu \mathrm{g} \cdot \mathrm{AFP} \cdot \mathrm{ml}^{-1}$ exhibit fungicidal effect and approximatlly $100 \%$ of $A$. alternata inhibition were observed. The effect of AFP to prevent the hyphal growth was illustrated in Figure 9, where low fungal growth have been found in treated fruits compared to untreated fruits.

The quantification of fungal DNA was calculated referred to a standard curve of different A. alternata DNA concentrations after the PCR has been done. The correlation between the obtained PCR-Fragments intensity and DNA concentrations using the exponential regression type correlation was carried out. Spices-specific PCR of isolated DNA from grown $A$. alternata plug during the storage for $15^{\circ} \mathrm{C}$ days at $20^{\circ} \mathrm{C}$ followed by measuring the PCR-Fragments intensity using Kodak program were carried out. All PCR tests were done under the same conditions and the final obtained DNA amounts from each treatment during the storage period were shown in Figure 10. It could be noticed that applying different concentrations of AFP have been shown to reduce the decayed area as mentioned and could affect the total DNA amount which related to the fungal biomass. The monitoring

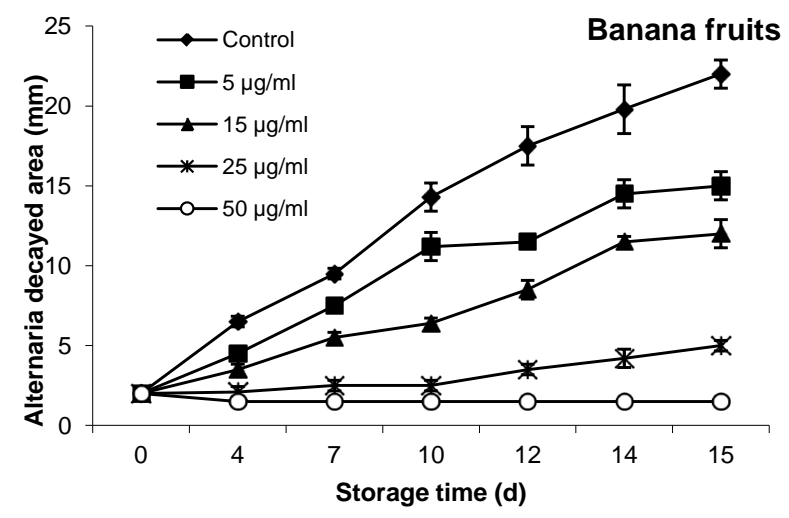

Figure 8. The inhibitory effect of AFP at different concentrations on growth of $A$. alternata in banana fruits during 15 days at $20^{\circ} \mathrm{C}$. The diameter of decayed area for triplicates experiment was expressed as $\mathrm{mm}$.
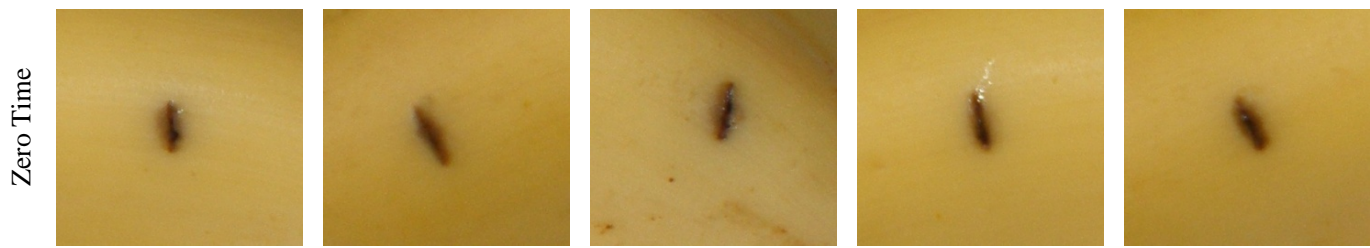

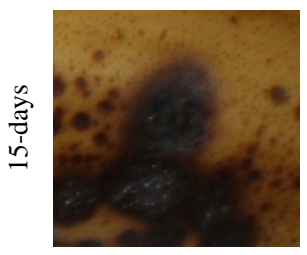

Control

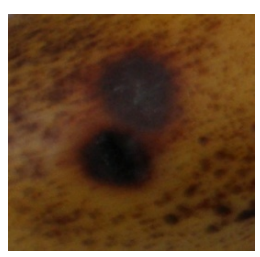

$5 \mu \mathrm{g} \cdot \mathrm{ml}^{-1}$

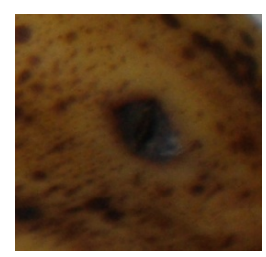

$15 \mu \mathrm{g} \cdot \mathrm{ml}^{-1}$

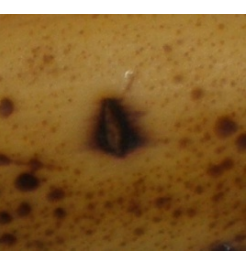

$25 \mu \mathrm{g} \cdot \mathrm{ml}^{-1}$

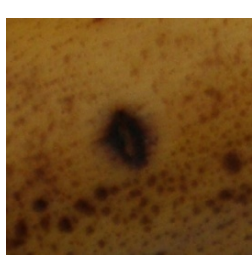

$50 \mu \mathrm{g} \cdot \mathrm{ml}^{-1}$

Figure 9. The inhibitory effect of AFP at different concentrations on growth of A. alternata in banana fruits after 15 days at $20^{\circ} \mathrm{C}$. The growth of Alernaria fungus is correlated to the AFP applied concentration. Some wounds were remarked at zero time and followed during the storage period. 


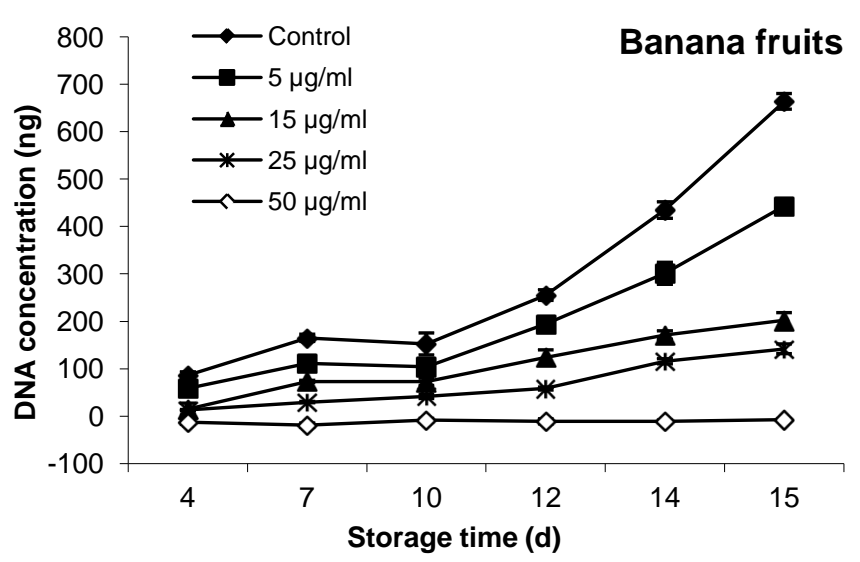

Figure 10. Quantification of A. alternata growth in banana fruits during 15 days at $20^{\circ} \mathrm{C}$. Obtained DNA amount was calculated refer to a standard curve which was performed using different DNA concentrations.

of DNA during storage period observed a positive relationship between the decayed area and DNA amounts (Figure 8 and Figure 10). To establish the efficiency of PCR method, the obtained DNAs from A. alternata plugs at 15-day were amplified and the PCR product were run on agaros gel $1.5 \%$, the obtained results were illustarted in Figure 11 as examplary shown for all treated banana on $15^{\text {th }}$ day. A positive relationship between the obtained results of decayed areas (Figure 8). Therefore, established relatively DNA quantification method facilitated the detection and quantification of A. alternata during storage period and may indicate the storage age prediction.

\section{Discussion}

Increasing social and economic implications caused by fungi means there is a constant striving to produce safer food and to develop new antifungal agents. In postharvest and handling of banana, where control of diseases is necessary to preserve the quality of the product, the use of synthetic fungicides, biological antagonists and physical treatments are integrated. AFP was not applied to prevent A. alternata growth during storage and handling of banana so far. A. giganteus was cultivated as described by [7], used by [34], with an additional heat shock after approximately $100 \mathrm{~h}$ of incubation and AFP purification was modified by using C-ph instead of CMC [35]. Isolation of AFP applying isoelectric focusing would be a possible way to separate pure AFP from $\alpha$-Sarcin and additional secreted high molecular weight proteins from A. giganteus culture supernatant according the IEP. The established procedure was able to isolated AFP regarding to the isoelectric point, where the AFP could be successfully separated at 8.59 to 9.8 (Figure 4). However, the AFP was not purified from A. giganteus using the isoelectric focusing so far. Meanwhile, many of antifungal protein have been isolated and purified by using the isoelectric focusing system [9]-[11]. The established purification protocol of AFP could be efficient and valuable in AFP purification and yield. Comparing to mentioned purification protocol by [2] [5]-[8] [34], the isoelectric focusing could be 5 days shorter in time and cheaper in cost with producing higher amount of active AFP. Therefore, it recommended to be used for scaling up the AFP production.

Notably; AFP affected the hyphal extension and the morphological shape of A. alternata. AFP was shown to be affecting the hyphae extension and the morphological shape. The inhibition zones which mediated by AFP as different concentrations demonstrated a positive relation between the concentration and the activity (Figure 5). This may be due to the influence on AFP hyphal extension by localisation on the outer membrane within defined areas cause short, thick and highly septated hyphae with constricted apical regions extruding from condensed mycelia [12] [29]. However, AFP shares several structural features with membrane acting proteins, such as an amphiphitic structure, a basic PI and the occurrence of eight cysteine residues, all involved in intermolecular disulfide bridges. These membrane-acting proteins have been shown to exert their antifungal activity by phospholipids-binding site [5] [15]. Also from the ability of AFP to cause swelling of hyphal tips, apical and subapical branching, and evoke cells that tend to burst exclusively at their hyphal apex. Furthermore, the protein 


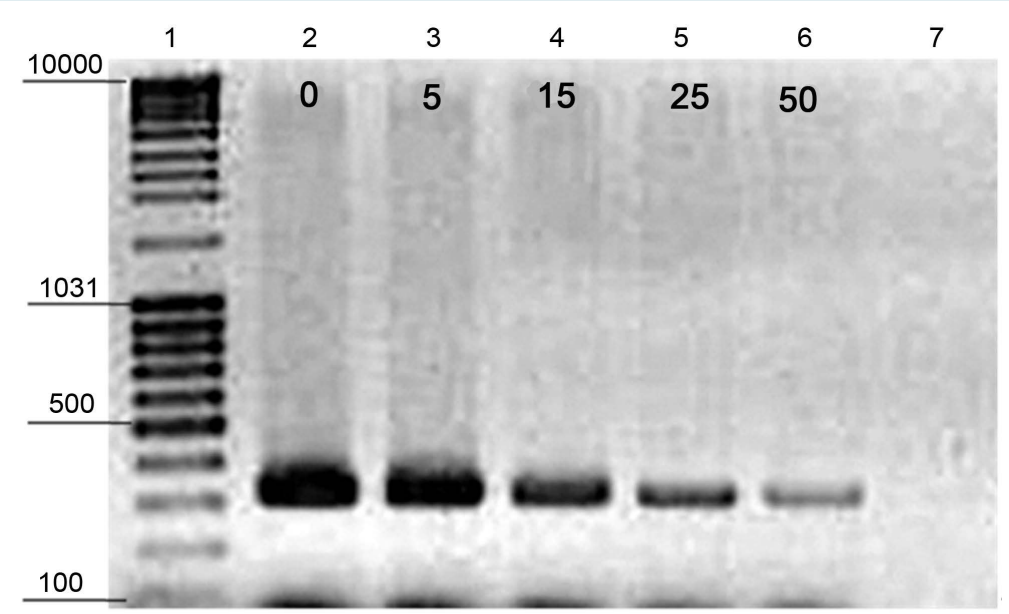

Figure 11. Species-specific PCR-DNA fragments of A. alternate. Lane 1, GeneRuler $^{\mathrm{TM}}$ DNA ladder Mix (100 - 10.000-bp). Lane 2 (0, control); 3 (5 $\left.\mu \mathrm{g} \cdot \mathrm{AFP} \cdot \mathrm{ml}^{-1}\right) ; 4\left(15 \mu \mathrm{g} \cdot \mathrm{AFP} \cdot \mathrm{ml}^{-1}\right) ; 5\left(25 \mu \mathrm{g} \cdot \mathrm{AFP} \cdot \mathrm{ml}^{-1}\right)$ and $6\left(50 \mu \mathrm{g} \cdot \mathrm{AFP} \cdot \mathrm{ml}^{-1}\right)$ as well as Lane 7 indicate to PCR negative control.

induces the protein kinase C (PKC)-dependent cell wall integrity pathway as compensatory response (Hagen et al., 2007). Our illustrated results in Figure 5 and Figure 6 are related to previous studies [2] [6] [12] [14] [36][38].

Antifungal activity of AFP against A. alternata was very efficient and completely inhibited at AFP concentrations $2 \mu \mathrm{g} \cdot \mathrm{ml}^{-1}$ and A. alternate was classified to be very sensitive toward AFP. The MIC calculated as the concentration, which inhibits 95\% fungal growth with our procedure. Various methods have determined the MIC of AFP, resulted different and sparse MIC values against some fungi. [5] [8] [23] [34] used also this mentioned procedure. Our results are in accordance to Thies [7] who divided all fungi into sensitive (0.1 to up to 100 $\mu \mathrm{g} / \mathrm{ml}$ ), moderately sensitive (120 to $400 \mu \mathrm{g} / \mathrm{ml}$ ) and resistant (no effect) fungi according to the AFP concentration which had an effect on fungal growth. MIC of tested A. alternata could be an indication of a receptor-mediated interaction of AFP with a membrane-based target. Fungi that exhibit this postulated receptor are highly sensitive to AFP, whereas fungi that lack this target are resistant. Our results exude that AFP concentration below a species specific MIC led to a fungistatic effect, whereas concentrations above the MIC resulted in a fungicidal effect [12] [39].

In order to test the AFP mode of action against some A. alternata the influx of fluorogenic SYTOX-Green dye through the cell membrane was established [23]. Likewise, AFP-induced membrane permeabilization was shown by the application of this technique [13]. Hence, only at concentrations that are ten- to hundred fold higher than the minimal inhibitory concentration, AFP can be detected intercellulary [12] [40]. It could qualitatively be explained that AFP readily permeabilizes the membrane of A. alternata strains at $10 \mu \mathrm{g} \cdot \mathrm{ml}^{-1}$ (Figure 7). The antifungal activity of AFP might be due to pores formation through the cell wall or penetrated the cell membranes by aiding of specific AFP receptors [13] [35]. As previously established, several models for the growth inhibitory effect of AFP could be explained, such as two-state model [41], according to these models, AFP would bind to membranes and at species-specific concentration, the conformation of AFP would change and would be able to enter the membrane and form pores. Theis [7] illustrated that AFP acts very specifically depends on AFP receptors. A similar receptor mediated interaction with membranes has been described for some plant defences [42] [43].

The abundance of A. alternata spores and the significant amount of hours with RH over $80 \%$ enhances the occurrence of both Alternaria rot, stem-end rots and black spots caused by this pathogen [44]. Thus, the efficacy of AFP in vivo was studied by evaluating the ability of four different AFP concentrations to inhibit the fungal infection. This study was carried out at $20^{\circ} \mathrm{C}$ and $90 \%-96 \%$ RH, only to study the effect of AFP on the fungal infection. The most active concentration was up $25 \mu \mathrm{g} \cdot \mathrm{ml}^{-1}$ as cause fungistatic activity while, at $50 \mu \mathrm{g} \cdot \mathrm{ml}^{-1} \mathrm{ex}-$ hibit a fungicidal effect on banana fruits. The results concluded that AFP significantly reduced the fungal growth by more than $75 \%$ by applying AFP at concentration of $25 \mu \mathrm{g} \cdot \mathrm{ml}^{-1}$ at $20^{\circ} \mathrm{C}$. Comparing the used concentration to have the same inhibition percentage (75\%) was about $1 \mu \mathrm{g} \cdot \mathrm{ml}^{-1}$ in vitro and $25 \mu \mathrm{g} \cdot \mathrm{ml}^{-1}$ in vivo. Generally, the 
AFP concentration to inhibit microbial growth in foods system was higher than in culture media. This may be due to the different in available nutrients, environments as well as AFP interaction with food substances. Moreover, a sensible amount of used AFP solution was absorbed through the plant tissues. Establishment of relatively DNA quantification method facilitated the detection and quantification of A. alternata during storage period. This technique is very effective, rapid, easy, reliable, reducing the consuming time and costs during detection of large amount of fruits in the large storage houses as tested before [23]. The contributed results from measuring the Alternaria decayed area and their isolated DNA exhibited a high degree of relationship as indicated the coefficient of determination values $\left(R^{2}\right)$, was in average of 0.92 . However, measuring the Alternaria decayed area recorded no increases in the infected area but, a slight increase in the DNA amount was observed at $25 \mu \mathrm{g} \cdot \mathrm{ml}^{-1}$ after 15 days. This may be due to A. alternata was grown inside the banana fruits tissues thereby increase the total DNA amount. The results were recently emphasised by [23].

\section{Conclusion}

In conclusion, the method described here is relatively easy to use, fast and sensitive and could be applied to purify AFP from the precipitated whole protein, which obtained from A. giganteus supernatant and provided more facilities including save time, costs and equipments. Purification of AFP using IEF system exhibits no effect on the AFP bioactivity which has not been used for purification of AFP so far. In addition, AFP appeared to be very efficient against the main fungal contaminants, mainly belonging to the genus Alternaria in vitro and in vivo. The established results from this study together with data from previous studies should provide a basis for the further applications. Finally, application of AFP is a very attractive method for controlling the fungal spoilage during storage and handling and considers being one of the most promising antifungal agents for the development of safer antifungal agents. Scaling up AFP production and purification are further required.

\section{Acknowledgements}

The author is very glad to acknowledge the Research Institute Chemical-Technical Analyses, Technical university of Berlin, Germany for providing with technical assistance during the purification of AFP using the isoelectric focusing technique and the WAP-DAAD-2013 mission for the financial support.

\section{References}

[1] Ng, T.B. (2013) Chapter 23-Antifungal and Antibacterial Peptides of Fungal Origin. In: Kastin, A.J., Ed., Handbook of Biologically Active Peptides, 2nd Edition, Academic Press, Boston, 157-161. http://dx.doi.org/10.1016/B978-0-12-385095-9.00023-3

[2] Liu, R., Huang, H.W., Yang, Q. and Liu, W. (2002) Purification of $\alpha$-Sarcin and an Antifungal Protein from Mold (Aspergillus giganteus) by Chitin Affinity Chromatography. Protein Expression and Purification, 25, 50-58. http://dx.doi.org/10.1006/prep.2001.1608

[3] Olmo, N., Turnay, J., de Buitrago, G.G., de Silanes, I.L., Gavilanes, J.G. and Lizarbe, M.A. (2001) Cytotoxic Mechanism of the Ribotoxin $\alpha$-Sarcin. European Journal of Biochemistry, 268, 2113-2123. http://dx.doi.org/10.1046/j.1432-1327.2001.02086.x

[4] Szappanos, H., Szigeti, G.P., Pál, B., Rusznák, Z., Szucs, G., Rajnavölgyi, É., Balla, J., Balla, G., Nagy, E., Leiter, É., Pócsi, I., Hagen, S., Meyer, V. and Csernoch, L. (2006) The Antifungal Protein AFP Secreted by Aspergillus giganteus Does Not Cause Detrimental Effects on Certain Mammalian Cells. Peptides, 27, 1717-1725. http://dx.doi.org/10.1016/j.peptides.2006.01.009

[5] Lacadena, J., Martinez del Pozo, A., Gasset, M., Patino, B., Campos-Olivas, R., Vazquez, C., Martinez-Ruiz, A., Mancheno, J.M., Onaderra, M. and Gavilanes, J.G. (1995) Characterization of the Antifungal Protein Secreted by the Mould Aspergillus giganteus. Archive of Biochemistry and Biophysics, 324, 273-281. http://dx.doi.org/10.1006/abbi.1995.0040

[6] Hao, J.-J., Xu, Y.-Z., Geng, C.-D., Liu, W.-Y., Wang, E.-D., Gong, Z.-Z. and Ulbrich, N. (1998) Purification of $\alpha$ Sarcin and an Antifungal Protein from Aspergillus giganteus by Blue Sepharose CL-6B Affinity Chromatography. Protein Expression and Purification, 14, 295-301. http://dx.doi.org/10.1006/prep.1998.0957

[7] Theis, T. (2003) Target Site and Mode of Action of the Antifungal Protein from Aspergillus giganteus. Ph.D. Thesis, Technische Universität, Berlin.

[8] Barakat, H., Spielvogel, A., Hassan, M., El-Desouky, A., El-Mansy, H., Rath, F., Meyer, V. and Stahl, U. (2010) The Antifungal Protein AFP from Aspergillus giganteus Prevents Secondary Growth of Different Fusarium Species on 
Barley. Applied Microbiology and Biotechnology, 87, 617-624. http://dx.doi.org/10.1007/s00253-010-2508-4

[9] Ghosh, M. (2009) Purification of a Lectin-Like Antifungal Protein from the Medicinal Herb, Withania somnifera. Fitoterapia, 80, 91-95. http://dx.doi.org/10.1016/j.fitote.2008.10.004

[10] Mhetras, N.C., Bastawde, K.B. and Gokhale, D.V. (2009) Purification and Characterization of Acidic Lipase from Aspergillus niger NCIM 1207. Bioresource Technology, 100, 1486-1490. http://dx.doi.org/10.1016/j.biortech.2008.08.016

[11] Iijima, S., Shiba, K., Inoue, J., Yoshida, T. and Kimura, M. (1997) Simultaneous Analysis of Microheterogeneity of Immunoglobulins and Serum Protein Fraction Using High-Voltage Isoelectric Focusing on Six Cellulose Acetate Membranes. Journal of Clinical Laboratory Analysis, 11, 220-224. http://dx.doi.org/10.1002/(SICI)1098-2825(1997)11:4<220::AID-JCLA8>3.0.CO;2-C

[12] Theis, T., Marx, F., Salvenmoser, W., Stahl, U. and Meyer, V. (2005) New Insights into the Target Site and Mode of Action of the Antifungal Protein of Aspergillus giganteus. Research in Microbiology, 156, 47-56. http://dx.doi.org/10.1016/j.resmic.2004.08.006

[13] Theis, T., Wedde, M., Meyer, V. and Stahl, U. (2003) The Antifungal Protein from Aspergillus giganteus Causes Membrane Permeabilization. Antimicrobial Agents and Chemotherapy, 47, 588-593. http://dx.doi.org/10.1128/AAC.47.2.588-593.2003

[14] Moreno, A.B., Penas, G., Rufat, M., Bravo, J.M., Estopa, M., Messeguer, J. and San Segundo, B. (2005) PathogenInduced Production of the Antifungal AFP Protein from Aspergillus giganteus Confers Resistance to the Blast Fungus Magnaporthe grisea in Transgenic Rice. Molecular Plant-Microbe Interaction, 18, 960-972. http://dx.doi.org/10.1094/MPMI-18-0960

[15] Shai, Y. (2002) Mode of Action of Membrane Active Antimicrobial Peptides. Biopolymers, 66, 236-248. http://dx.doi.org/10.1002/bip.10260

[16] Ferket, K.K.A., Levery, S.B., Park, C., Cammue, B.P.A. and Thevissen, K. (2003) Isolation and Characterization of Neurospora crassa Mutants Resistant to Antifungal Plant Defensins. Fungal Genetics and Biology, 40, 176-185. http://dx.doi.org/10.1016/S1087-1845(03)00085-9

[17] Park, C., Bennion, B., Francois, I.E., Ferket, K.K., Cammue, B.P., Thevissen, K. and Levery, S.B. (2005) Neutral Glycolipids of the Filamentous Fungus Neurospora crassa: Altered Expression in Plant Defensin-Resistant Mutants. Journal of Lipid Research, 46, 759-768. http://dx.doi.org/10.1194/jlr.M400457-JLR200

[18] Hagen, S., Marx, F., Ram, A.F. and Meyer, V. (2007) The Antifungal Protein AFP from Aspergillus giganteus Inhibits Chitin Synthesis in Sensitive Fungi. Applied and Environmental Microbiology, 73, 2128-2134. http://dx.doi.org/10.1128/AEM.02497-06

[19] Liu, H., Kauffman, S., Becker, J.M. and Szaniszlo, P.J. (2004) Wangiella (Exophiala) dermatitidis WdChs5p, a Class V Chitin Synthase, Is Essential for Sustained Cell Growth at Temperature of Infection. Eukaryotic Cell, 3, 40-51. http://dx.doi.org/10.1128/EC.3.1.40-51.2004

[20] Parkunan, V., Li, S., Fonsah, E.G. and Ji, P. (2013) First Report of Alternaria Leaf Spot of Banana Caused by Alternaria alternata in the United States. Plant Disease, 97, 1116. http://dx.doi.org/10.1094/PDIS-01-13-0007-PDN

[21] Wiest, P.M., Wiese, K., Jacobs, M.R., Morrissey, A.B., Abelson, T.I., Witt, W. and Lederman, M.M. (1987) Alternaria Infection in a Patient with Acquired Immunodeficiency Syndrome: Case Report and Review of Invasive Alternaria Infections. Reviews of Infectious Diseases, 9, 799-803.

[22] Ostry, V. (2008) Alternaria Mycotoxins: An Overview of Chemical Characterization, Producers, Toxicity, Analysis and Occurrence in Foodstuffs. World Mycotoxin Journal, 1, 175-188. http://dx.doi.org/10.3920/WMJ2008.x013

[23] Barakat, H., Hassan, M., El-Desouky, A.I., Stahl, U. and El-Mansy, H. (2012) The Antifungal Protein AFP from Aspergillus giganteus Prevents Altarnaria Spoilage on Tomato and Mango Fruits during Storage. The 1st International Conference on Biotechnology Applications in Agriculture, Benha University, Moshtohor and Hurghada, 18-22 February 2012, 29-38.

[24] Meyer, V. (2008) A Small Protein That Fights Fungi: AFP as a New Promising Antifungal Agent of Biotechnological Value. Applied Microbiology and Biotechnology, 78, 17-28. http://dx.doi.org/10.1007/s00253-007-1291-3

[25] Konstantinova, P., Bonants, P.J.M., Van Gent-Pelzer, M.P.E., Van Der Zouwen, P. and Van Den Bulk, R. (2002) Development of Specific Primers for Detection and Identification of Altevnavia spp. in Carrot Material by PCR and Comparison with Blotter and Plating Assays. Mycological Research, 106, 23-33. http://dx.doi.org/10.1017/S0953756201005160

[26] Merril, C.R. and Harrington, M.G. (1984) "Ultrasensitive” Silver Stains: Their Use Exemplified in the Study of Normal Human Cerebrospinal Fluid Proteins Separated by Two-Dimensional Electrophoresis. Clinical Chemistry, 30, 1938-1942.

[27] Bradford, M.M. (1976) A Rapid and Sensitive Method for the Quantitation of Microgram Quantities of Protein Utiliz- 
ing the Principle of Protein-Dye Binding. Analytical Biochemistry, 72, 248-254.

http://dx.doi.org/10.1016/0003-2697(76)90527-3

[28] Roberts, W.K. and Selitrennikoff, C.P. (1986) Isolation and Partial Characterization of Two Antifungal Proteins from Barley. Biochimica et Biophysica Acta (BBA)-General Subjects, 880, 161-170. http://dx.doi.org/10.1016/0304-4165(86)90076-0

[29] Vila, L., Lacadena, V., Fontanet, P., del Pozo, A.M. and Segundo, B.S. (2001) A Protein from the Mold Aspergillus giganteus Is a Potent Inhibitor of Fungal Plant Pathogens. Molecular Plant-Microbe Interactions, 14, 1327-1331. http://dx.doi.org/10.1094/MPMI.2001.14.11.1327

[30] Hu, X. and Reddy, A.S. (1997) Cloning and Expression of a PR5-Like Protein from Arabidopsis: Inhibition of Fungal Growth by Bacterially Expressed Protein. Plant Molecular Biology, 34, 949-959.

[31] Thevissen, K., Terras, F.R. and Broekaert, W.F. (1999) Permeabilization of Fungal Membranes by Plant Defensins Inhibits Fungal Growth. Applied and Environmental Microbiology, 65, 5451-5458.

[32] Fredlund, E., Gidlund, A., Olsen, M., Börjesson, T., Spliid, N.H.H. and Simonsson, M. (2008) Method Evaluation of Fusarium DNA Extraction from Mycelia and Wheat for Down-Stream Real-Time PCR Quantification and Correlation to Mycotoxin Levels. Journal of Microbiological Methods, 73, 33-40. http://dx.doi.org/10.1016/j.mimet.2008.01.007

[33] Sambrook, J. and Russell, D.W. (2001) Molecular Cloning: A Laboratory Manual. Cold Spring Harbor Laboratory Press, New York.

[34] Hagen, S. (2006) Identification of Fungal Constituents that Determine the Sensitivity of Fungi towards the Antifungal Protein (AFP) of Aspergillus giganteus. Ph.D. Thesis, Technische Universität, Berlin.

[35] Barakat, H., Hassan, M., El-Desouky, A.I., El-Mansy, H. and Stahl, U. (2012) Purification of Antifungal Protein (AFP) from Aspergillus giganteus and Its Antifungal Activity. The 1st International Conference on Biotechnology Applications in Agriculture, Benha University, Moshtohor and Hurghada, 18-22 February 2012, 15-28.

[36] Moreno, A.B., Del Pozo, A.M., Borja, M. and Segundo, B.S. (2003) Activity of the Antifungal Protein from Aspergillus giganteus against Botrytis cinerea. Phytopathology, 93, 1344-1353. http://dx.doi.org/10.1094/PHYTO.2003.93.11.1344

[37] Martinez Del Pozo, A., Lacadena, V., Mancheno, J.M., Olmo, N., Onaderra, M. and Gavilanes, J.G. (2002) The Antifungal Protein AFP of Aspergillus giganteus Is an Oligonucleotide/Oligosaccharide Binding (OB) Fold-Containing Protein that Produces Condensation of DNA. The Journal of Biological Chemistry, 277, 46179-46183. http://dx.doi.org/10.1074/jbc.M207472200

[38] Marx, F., Salvenmoser, W., Kaiserer, L., Graessle, S., Weiler-Görz, R., Zadra, I. and Oberparleiter, C. (2005) Proper Folding of the Antifungal Protein PAF Is Required for Optimal Activity. Research in Microbiology, 156, 35-46. http://dx.doi.org/10.1016/j.resmic.2004.07.007

[39] Takeshita, N., Yamashita, S., Ohta, A. and Horiuchi, H. (2006) Aspergillus nidulans Class V and VI Chitin Synthases CsmA and CsmB, Each with a Myosin Motor-Like Domain, Perform Compensatory Functions That Are Essential for Hyphal Tip Growth. Molecular Microbiology, 59, 1380-1394. http://dx.doi.org/10.1111/j.1365-2958.2006.05030.x

[40] Moreno, A.B., Martinez Del Pozo, A. and San Segundo, B. (2006) Biotechnologically Relevant Enzymes and Proteins. Antifungal Mechanism of the Aspergillus giganteus AFP against the Rice Blast Fungus Magnaporthe grisea. Applied Microbiology and Biotechnology, 72, 883-895. http://dx.doi.org/10.1007/s00253-006-0362-1

[41] Huang, H.W. (2000) Action of Antimicrobial Peptides: Two-State Model. Biochemistry, 39, 8347-8352. http://dx.doi.org/10.1021/bi000946l

[42] Thevissen, K., Ferket, K.K.A., François, I.E.J.A. and Cammue, B.P.A. (2003) Interactions of Antifungal Plant Defensins with Fungal Membrane Components. Peptides, 24, 1705-1712. http://dx.doi.org/10.1016/j.peptides.2003.09.014

[43] Thevissen, K., Osborn, R.W., Acland, D.P. and Broekaert, W.F. (2000) Specific Binding Sites for an Antifungal Plant Defensin from Dahlia (Dahlia merckii) on Fungal Cells Are Required for Antifungal Activity. Molecular Plant-Microbe Interactions, 13, 54-61. http://dx.doi.org/10.1094/MPMI.2000.13.1.54

[44] Kobiler, I., Shalom, Y., Roth, I., Akerman, M., Vinokur, Y., Fuchs, Y. and Prusky, D. (2001) Effect of 2,4-Dichlorophenoxyacetic Acid on the Incidence of Side and Stem End Rots in Mango Fruits. Postharvest Biology and Technology, 23, 23-32. http://dx.doi.org/10.1016/S0925-5214(01)00092-8 
Scientific Research Publishing (SCIRP) is one of the largest Open Access journal publishers. It is currently publishing more than 200 open access, online, peer-reviewed journals covering a wide range of academic disciplines. SCIRP serves the worldwide academic communities and contributes to the progress and application of science with its publication.

Other selected journals from SCIRP are listed as below. Submit your manuscript to us via either submit@scirp.org or Online Submission Portal.
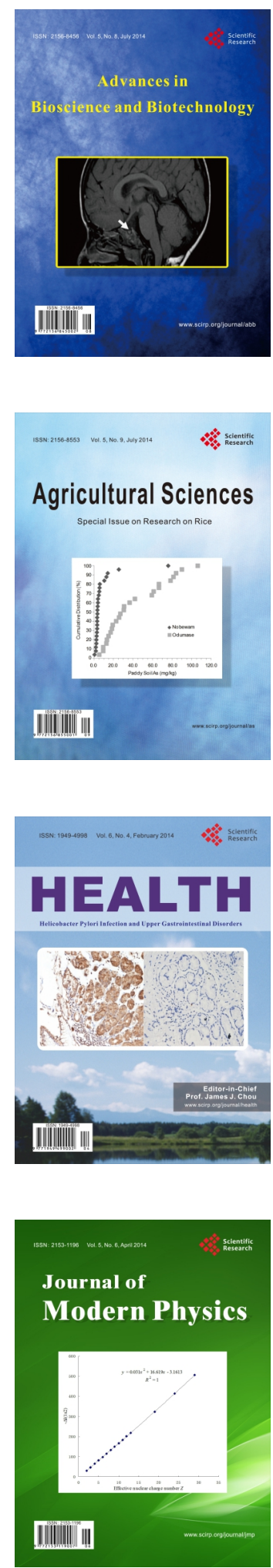
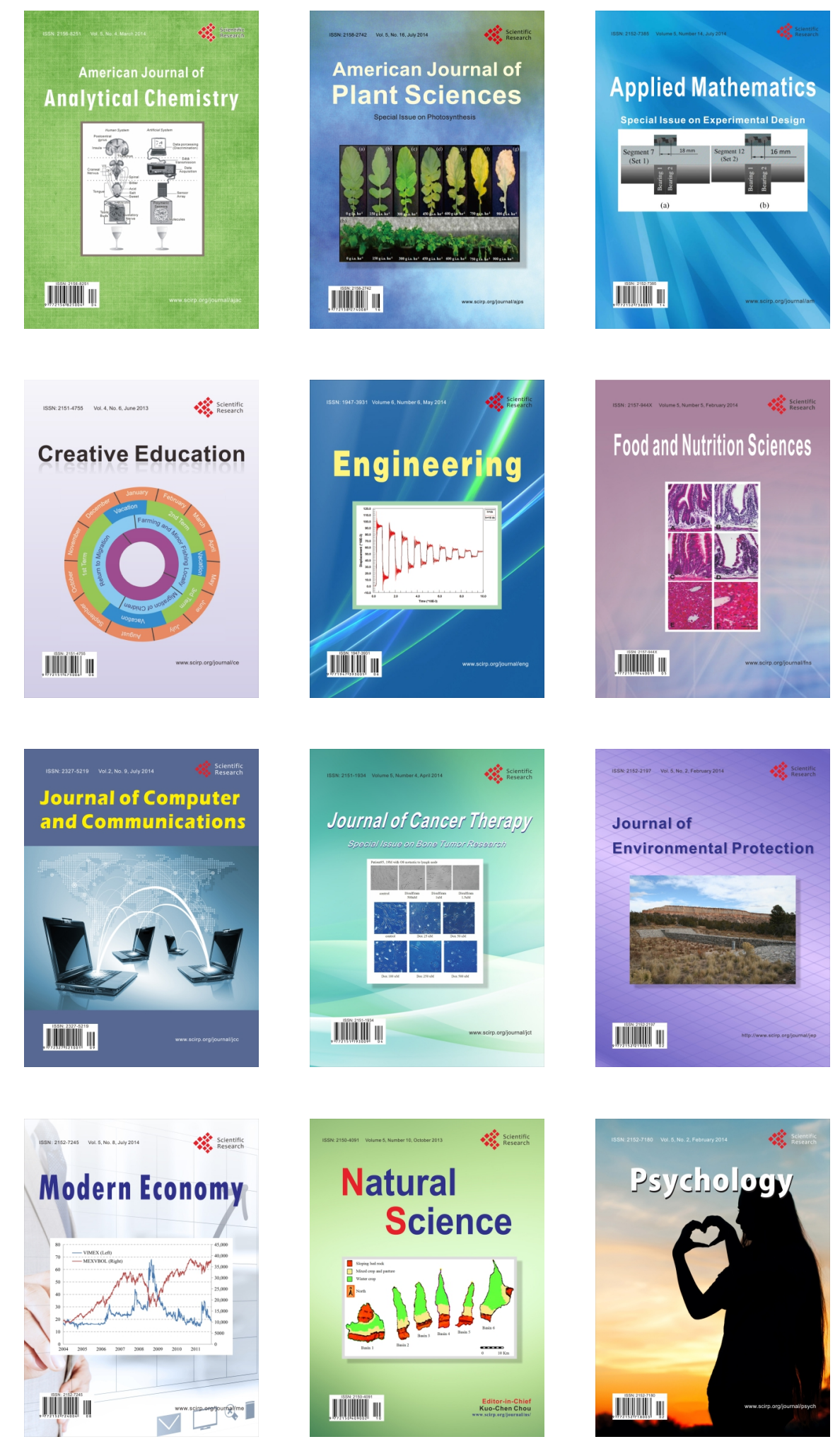